\title{
GREEN HERBAGE YIELD ASSESSMENTS OF MAIZE CULTIVARS THROUGH GGE BIPLOT ANALYSIS METHOD
}

\author{
Kagan KOKTEN ${ }^{1}$, Mahmut KAPLAN ${ }^{2}$, Mevlut AKCURA \\ ${ }^{1}$ Bingol University, Faculty of Agriculture, Department of Field Crops, Bingol, TURKEY \\ ${ }^{2}$ Erciyes University, Faculty of Agriculture, Department of Field Crops, Kayseri, TURKEY \\ ${ }^{3}$ Canakkale Onsekiz Mart University, Faculty of Agriculture, Department of Field Crops, Canakkale, \\ TURKEY \\ *Corresponding author: mahmutkaplan5@hotmail.com
}

Received: 07.06.2017

\begin{abstract}
The present study was conducted to assess green herbage yields of hybrid maize cultivars grown under different environments for two years. GGE biplot analysis method and regression coefficients were used to assess genotype $x$ environment interaction and to identify the most stable cultivars for green herbage yield. Experiments were conducted in six different environments, green herbage yields in the environments varied between $6.0 \mathrm{t} \mathrm{da}^{-1}(\mathrm{E} 5)$ and $10.4 \mathrm{t} \mathrm{da}^{-1}(\mathrm{E} 1)$ and green herbage yield yields of the cultivars varied between $6.8 \mathrm{t}$ $\mathrm{da}^{-1}$ (G14) and $10.9 \mathrm{t} \mathrm{da}^{-1}$ (G18). In GGE biplot analysis, the first two principle component (PC) axis explained about $82.45 \%$ of total variation. The genotypes with high PC1 and low PC2 values and regression coefficient of 1.0 were assessed as stable. The cultivar Safak $($ G18) with such values was identified as the most stable cultivar. The regression coefficient of 1.0 and the greatest green herbage yield proved the stability of that cultivar. The cultivars with higher PC1 and lower PC2 values [30B74 (G2), Seme Kukuruza 877 (G22), ADV 2898 (G24), Wayne (G17), and Safak (G18)] generally had higher green herbage yield than the general average. Safak (G18), 30B74 (G2), Seme Kukuruza 877 (G22), ADV 2898 (G24) and Wayne (G17) cultivars can be use green herbage yield production in south eastern Anatolia will allow the growers to have a profitable production.
\end{abstract}

Key words: environment, GGE biplot, hybrid maize, green herbage yield

\section{INTRODUCTION}

Silage is widely used in livestock feeding in developed countries since it has several superior attributes over the regular feed sources such as quite high moisture content and nutritive value, easy preservation for long durations, easy digestion because of fermentation of (Kaplan et al., 2016). High yields of maize cultivars, easy harvest and ensilage of them, their taste and heartily consumption by livestock (Neylon and Kung, 2003; Kaplan, 2005), availability for ensilage, high adaptation capability have made maize a significant silage crop worldwide (McDonald et al., 1991; Meeske et al., 1993). Maize is also significant silage crop in Turkey.

Researches have been conducted with multienvironments to identify high-yield and stable genotypes (Akcura et al., 2005). In such researches, generally a certain number of genotypes are assessed with regard to various targeted attributes under different environmental conditions for years. However, since the genotypes exhibit different responses to different environments with regard to investigated attributes, it is quite hard to comment on genotype $\mathrm{x}$ environment interactions with classical research methods (Rakshit et al., 2012). Therefore, different analysis and assessment methods have been developed for multi-environment studies. Some of these methods are regression coefficient and sum of squares from regression (Eberhart and Russel, 1966), stability variance (Shukla, 1972), coefficient of variability (Francis and Kanneberg, 1978), additive main effects and multiplicative interaction (AMMI) (Gauch and Zobel, 1988) and GGE biplot (Yan et al., 2000) methods.

In majority of above-mentioned methods, while only the stability of genotypes was taken into consideration, assessments are not made on environments. Therefore, some researchers preferred to assess genotype stability with more than one method rather than a single method (Flores et al., 1998; Akcura et al., 2006). Some researchers have found regression method insufficient in stability analysis while assessing GxE interactions (Zobel et al., 1988; Nachit et al., 1992; Annicchiarico, 1997; Kandus et al., 2010; Yan, 2014). 
In recent years, GGE biplot analysis has been used in multi-environment yield experiments. The method allows the researcher an efficient assessment of both the genotypes and environments (Yan, 2014). In GGE biplot method, genotype $\mathrm{x}$ environment interaction is separated into PC1 and PC2 axis with principle component analysis. With the graphs created based on these two axes, it is quite easy to comment on genotype $\mathrm{x}$ environment interaction and both the genotypes and the environments can reliably be assessed (Yan and Hunt, 1998; Yan, 1999; Yan et al., 2000; Akcura et al., 2011).
The present study was conducted with 25 hybrid maize cultivars in 6 different environments to assess the genotype $\mathrm{x}$ environment interaction with regard to silage yield and to identify the cultivars with high silage yield and stability.

\section{MATERIALS AND METHODS}

Silage maize genotypes used in this study and their supplier institutions are listed in Table 1.

Table 1. Silage maize genotypes and supplier organizations

\begin{tabular}{|c|c|c|}
\hline No & Genotype & Supplier Organization \\
\hline 1 & $31 \mathrm{P} 41$ & Pioneer Seed Company \\
\hline 2 & 30B74 & Pioneer Seed Company \\
\hline 3 & $31 \mathrm{Y} 43$ & Pioneer Seed Company \\
\hline 4 & $31 \mathrm{~A} 34$ & Pioneer Seed Company \\
\hline 5 & $12-219$ & Panam France Seed Company \\
\hline 6 & $12-218$ & Panam France Seed Company \\
\hline 7 & $12-231 \mathrm{HO}$ & Panam France Seed Company \\
\hline 8 & DKC 955 & Monsanto Company \\
\hline 9 & DKC 6903 & Monsanto Company \\
\hline 10 & DKC 6589 & Monsanto Company \\
\hline 11 & DKC 7211 & Monsanto Company \\
\hline 12 & DKC 6590 & Monsanto Company \\
\hline 13 & DIAN & Panam France Seed Company \\
\hline 14 & MARVIN & Panam France Seed Company \\
\hline 15 & ELDORA & Panam France Seed Company \\
\hline 16 & WAYNE & Italy Venturoli \\
\hline 17 & SAFAK & Western Mediterranean Agricultural Research Institute \\
\hline 18 & BATEM EFE & Western Mediterranean Agricultural Research Institute \\
\hline 19 & BURAK & Western Mediterranean Agricultural Research Institute \\
\hline 20 & SEME KUKURUZA 877 & Serbia Zemun Polje \\
\hline 21 & SEME KUKURUZA 873 & Serbia Zemun Polje \\
\hline 22 & ADV 2898 & Limagrain Seed Breeding and Production Company \\
\hline 23 & R.U 4 H.D & Pioneer Seed Company \\
\hline 24 & TUONO & Beta Agriculture and Trade Company \\
\hline 25 & TRUVA & Limagrain Seed Breeding and Production Company \\
\hline
\end{tabular}

Experiments were conducted in Diyarbakir-Bismil with an altitude of $535 \mathrm{~m}$, Elazig with an altitude of 1070 $\mathrm{m}$ and Bingol with an altitude of $1153 \mathrm{~m}$ during the growing seasons of 2014 and 2015 in randomized blocks design with 3 replications. Experimental plots were $5 \mathrm{~m}$ long. Each plot had 4 rows with $70 \mathrm{~cm}$ row spacing and 15 $\mathrm{cm}$ on-row plant spacing. Sowing was performed as to have 33 seeds per row. Before sowing, $80 \mathrm{~kg}$ nitrogen $(\mathrm{N})$, $80 \mathrm{~kg}$ phosphorus $\left(\mathrm{P}_{2} \mathrm{O}_{5}\right)$ and $80 \mathrm{~kg}$ potassium $\left(\mathrm{K}_{2} \mathrm{O}\right)$ fertilizers were supplied per hectare. When the plants reached to 50-60 $\mathrm{cm}$ heights, dressing fertilizer was applied with hoeing and at tassel formation period as to have a total of $150 \mathrm{~kg} \mathrm{ha}^{-1}$ nitrogen $(\mathrm{N})$. Throughout the growing season, two hoeing and 1 earthing were performed.

Climate parameters and soil characteristics of experimental sites, number of irrigations and sowing dates are provided in Table 2. In all three provinces, precipitations during the growing season were higher in the first year. Experimental sites have loamy soil texture with slightly alkaline structure in Diyarbakir and Elazig provinces (respectively with a $\mathrm{pH}$ of 7.73 and 7.78 ) and slightly acidic structure in Bingol province (with a $\mathrm{pH}$ of 6.37). The lime content was medium in Diyarbakir and Elazig and low in Bingol province (Table 2). 
Table 2. Data for experimental sites and experiments details

\begin{tabular}{|c|c|c|c|c|c|c|c|c|c|}
\hline \multicolumn{10}{|c|}{ Mean Temperatures $\left({ }^{\circ} \mathrm{C}\right)$} \\
\hline & \multicolumn{3}{|c|}{ Long term } & \multicolumn{6}{|c|}{ Growing seasons/Codes/ Environments } \\
\hline Months & E1-E4 & E2-E5 & E3-E6 & E1* & E2 & E3 & E4 & E5 & E6 \\
\hline April & 13.5 & 13.2 & 10.7 & 14.7 & 14.1 & 14.3 & 13.1 & 11.0 & 10.9 \\
\hline May & 19.3 & 17.7 & 16.3 & 19.7 & 19.1 & 18.5 & 19.4 & 17.6 & 16.6 \\
\hline June & 26.7 & 22.3 & 22.1 & 26.5 & 24.0 & 24.0 & 25.9 & 24.0 & 22.9 \\
\hline July & 31.4 & 28.1 & 26.7 & 31.5 & 29.6 & 29.4 & 29.7 & 28.9 & 27.9 \\
\hline August & 30.7 & 27.7 & 26.3 & 31.1 & 29.3 & 30.0 & 28.7 & 28.7 & 27.5 \\
\hline \multicolumn{10}{|c|}{ Experiments details } \\
\hline \multicolumn{4}{|c|}{ Sowing date } & 8.04 & 12.04 & 5.05 & 21.04 & 18.04 & 4.05 \\
\hline \multirow{2}{*}{\multicolumn{4}{|c|}{ Harvest date }} & 21.07 & 8.08 & 29.08 & 01.08 & 15.08 & 27.08 \\
\hline \multirow{2}{*}{\multicolumn{3}{|c|}{$\begin{array}{l}\text { Growing season precipitation }(\mathrm{mm}) \\
\text { Altitude (m.a.s.l) }\end{array}$}} & & 110.7 & 121.5 & 135.8 & 67.2 & 64.8 & 96.6 \\
\hline & & & & 535 & 1070 & 1153 & 535 & 1070 & 1153 \\
\hline \multicolumn{4}{|c|}{ Irrigation** } & $100 \times 4$ & $100 \times 4$ & $100 \times 4$ & $100 \times 4$ & $100 \times 4$ & $100 \times 4$ \\
\hline
\end{tabular}

*E1-E4 = Diyarbakir, E2-E5= Elaziğ, E3-E6= E3=Bingol Soil Types: Environments E1-E4: pH= 7.73 Loamy, medium lime; Environments E2-E5 $\mathrm{pH}=7.78$ Loamy, medium lime; Environments E3-E6 pH=6.37 Loamy, low lime, $* * 100 x 4$ : Experimental plots were flooded to the field capacity 4 times throughout the growing season

\section{Data collection and analysis}

All hybrid maize cultivars were manually harvested at milk-dough stage (about 30\% dry matter). Middle two rows were harvested and the side rows were omitted as to consider the side effect. Plant samples were weighed and green herbage yields were determined in ton $\mathrm{da}^{-1}$. Resultant data were subjected to variance analysis with SAS software (SAS, 2014). GGE biplot analysis was performed with GGE biplot GUI of R statistical software. The genotype and environment-focused biplot graphs created by using PC1 and PC2 values were used to assess genotypes and environments (R Development Core Team, 2008).

\section{RESULTS AND DISCUSSION}

Pooled analysis of variance indicated that genotype, environment and genotype $\mathrm{x}$ environment interaction had significant effects $(\mathrm{P}<0.01)$ on green herbage yield yields of maize cultivars. This result showed that green herbage yield were significantly influenced by environment (E) which accounted for $37.93 \%$ of the total variation in yield, while genotype (G) and genotype $x$ environment interaction (GEI) explained 14.94 and $19.53 \%$ of the variation in yields, respectively (Table 3 ).

Table 3. Analyses of variance for green herbage yield $\left(\mathrm{t} \mathrm{da}^{-1}\right)$ across 6 environments of Eastern Anatolia of Turkey.

\begin{tabular}{lcccc}
\hline Source & DF & Sum of squares & Mean square & Explained variation (\%) \\
\hline $\mathrm{E}$ & 5 & 1104953 & $220990^{* *}$ & 37.93 \\
$\mathrm{R}(\mathrm{E})$ & 12 & 81378 & 6781 & 14.94 \\
$\mathrm{G}$ & 24 & 435758 & $18156^{* *}$ & 19.53 \\
$\mathrm{E}^{*} \mathrm{G}$ & 120 & 568875 & $4740^{* *}$ & \\
Error & 288 & 722545 & 2508 & \\
Total & 449 & 2913511 & & \\
\hline Repeatability $\left(\mathrm{R}^{2}\right): 0.75$, Coefficient of variation $(\%): 19.45$, Mean: 8.41 ton da $^{-1}$ &
\end{tabular}

The effect of GEI was all most three times higher than that the effect of G. The magnitude of GEI as compared to $G$ suggested the possible existence of different mega environments. The partitioning of GGE through GGE biplot analysis showed that PC1 and PC2 accounted for 66.18 and $16.27 \%$ of GGE sum of squares, respectively, explaining $82.45 \%$ of total variation (Figure 1).

Experiments were conducted in six different environments and average green herbage yields in the different environments varied between $6.0 \mathrm{t} \mathrm{da}^{-1}$ (E5) and
$10.4 \mathrm{t} \mathrm{da}^{-1}$ (E1). Mean green herbage yield yields of maize cultivars varied between $6.8 \mathrm{t} \mathrm{da}^{-1}$ (G14) and $10.9 \mathrm{t} \mathrm{da}^{-1}$ (G18). Regression coefficients (b values) commonly used to assess the stability of genotypes are provided in Table 4. The regression coefficients of the cultivars varied between 0.42 (G17) and 1.62 (G14). For stable genotypes, $\mathrm{b}$ value should be 1.0 or be greater than the general average. Based on current $b$ values, the cultivar G18 (Safak) with the greatest green herbage yield $\left(10.6 \mathrm{t} \mathrm{da}^{-1}\right)$ and a regression coefficient of 1.0 was identified as the most stable genotype (Table 4). 


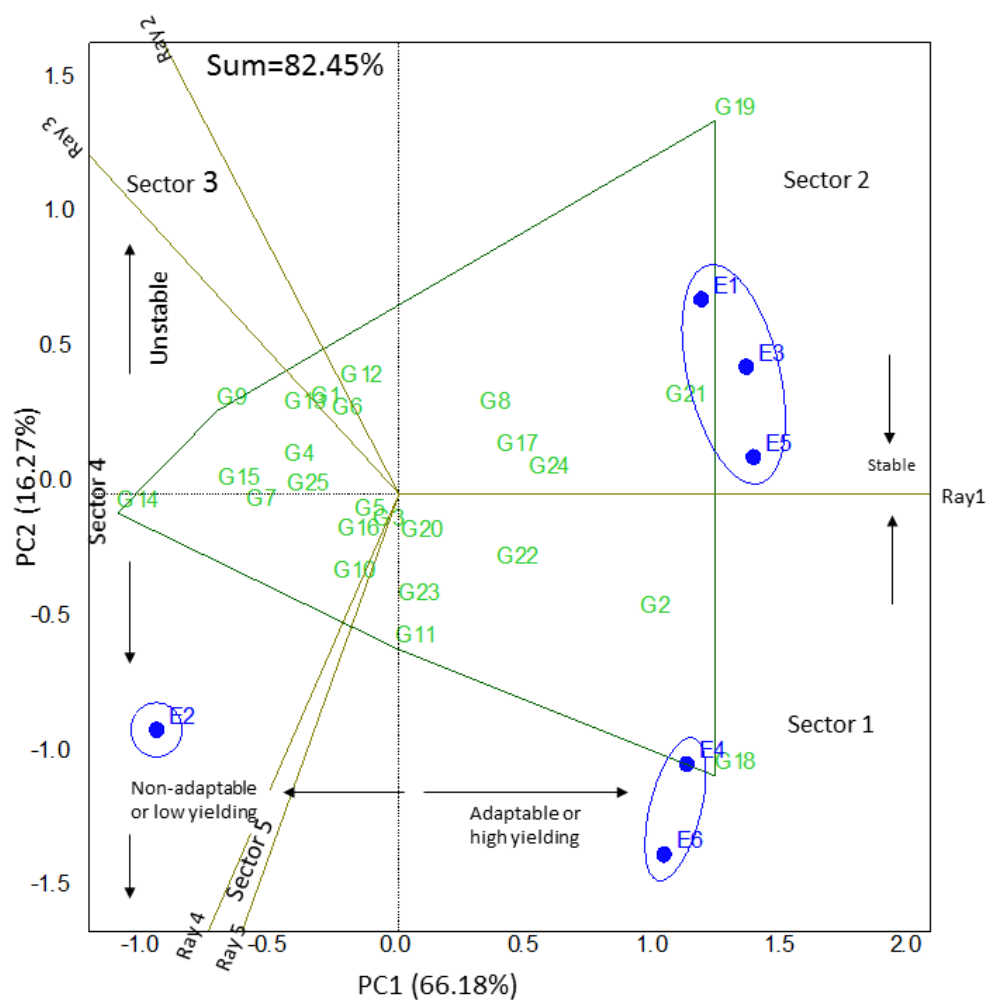

Figure 1. Polygon views of the GGE biplot based on symmetrical scaling of genotypes and environments for green herbage yield.

Table 4. Genotype and Environment code, mean green herbage yield $\left(\mathrm{t} \mathrm{da}^{-1}\right)$ and test environment mean $\left(\mathrm{t} \mathrm{da}^{-1}\right)$ of 25 maize cultivars across six environments in Eastern Anatolia Region of Turkey

\begin{tabular}{|c|c|c|c|c|c|c|c|c|c|}
\hline $\mathbf{G}$ & Genotypes & E1 & E2 & E3 & E4 & E5 & E6 & Mean & b value \\
\hline G1 & 31P41 & 10.5 & 10.1 & 6.2 & 6.8 & 5.4 & 6.8 & 7.6 & 1.21 \\
\hline G2 & $30 B 74$ & 11.9 & 9 & 9.3 & 11.2 & 7 & 10.1 & 9.7 & $0.71 * *$ \\
\hline G3 & $31 Y 43$ & 10.3 & 10.5 & 6.5 & 8.2 & 6 & 7.7 & 8.2 & 1.08 \\
\hline G4 & $31 \mathrm{~A} 34$ & 10.3 & 10.9 & 6.5 & 7 & 4.8 & 6.9 & 7.7 & 1.32 \\
\hline G5 & $12-219$ & 10.9 & 10 & 5.8 & 7.9 & 5.1 & 8.1 & 8 & 1.31 \\
\hline G6 & $12-218$ & 10.8 & 9.9 & 6 & 7.8 & 5.5 & 6.5 & 7.7 & $1.25^{*}$ \\
\hline G7 & $12-231 \mathrm{H} 0$ & 8.7 & 10.5 & 4.4 & 7 & 5.7 & 6.9 & 7.2 & 1.11 \\
\hline G8 & DKC 955 & 9.6 & 7.9 & 7.5 & 10.2 & 6.6 & 6.5 & 8 & $0.56 * *$ \\
\hline G9 & DKC 6903 & 9 & 10.5 & 5.7 & 6 & 4.6 & 6.2 & 7 & 1.17 \\
\hline G10 & DKC 6589 & 9.5 & 9.9 & 5.3 & 7.3 & 5.3 & 9 & 7.7 & 1.06 \\
\hline G11 & DKC 7211 & 8.8 & 10.2 & 6.1 & 9.9 & 6.1 & 8.3 & 8.2 & 0.84 \\
\hline G12 & DKC 6590 & 10.3 & 8.9 & 6 & 7.9 & 5.1 & 6.5 & 7.4 & 1.11 \\
\hline G13 & R.U 4 H.D & 10.2 & 10.5 & 6.2 & 7.9 & 5 & 5.6 & 7.6 & $1.30^{*}$ \\
\hline G14 & DIAN & 8.8 & 11.7 & 3.9 & 6.4 & 3.6 & 6.1 & 6.8 & $1.62 * *$ \\
\hline G15 & MARVIN & 8.3 & 10.3 & 4.3 & 7 & 5.3 & 6.5 & 6.9 & 1.09 \\
\hline G16 & ELDORA & 9.5 & 9.6 & 5.6 & 8.7 & 4.9 & 7.7 & 7.6 & 1.11 \\
\hline G17 & WAYNE & 9.8 & 8.5 & 8 & 7.8 & 7.3 & 8.7 & 8.4 & $0.42 * *$ \\
\hline G18 & SAFAK & 13.9 & 10.7 & 7.9 & 12.3 & 9.2 & 11.3 & 10.9 & 1 \\
\hline G19 & BATEM EFE & 17 & 7.7 & 10.3 & 7.6 & 9.2 & 7.2 & 9.8 & 0.97 \\
\hline G20 & TUONO & 11 & 11.3 & 8.1 & 7.5 & 6.1 & 8.5 & 8.7 & 1.07 \\
\hline G21 & BURAK & 13.1 & 8.7 & 10.4 & 9.6 & 8.2 & 8.6 & 9.8 & $0.59 * *$ \\
\hline G22 & SEME KUKURUZA877 & 9.6 & 8.3 & 7 & 9.1 & 6.5 & 9.6 & 8.3 & $0.56^{* *}$ \\
\hline G23 & SEME KUKURUZA873 & 9.3 & 10 & 7 & 9 & 5.3 & 8.7 & 8.2 & 0.89 \\
\hline G24 & ADV 2898 & 11.2 & 8.1 & 7.5 & 10.4 & 6.2 & 8 & 8.6 & $0.83 *$ \\
\hline G25 & TRUVA & 7.9 & 9.9 & 5.2 & 8 & 6 & 6.5 & 7.3 & 0.82 \\
\hline Average & & 10.4 & 9.7 & 6.7 & 8.4 & 6 & 7.7 & 8.1 & \\
\hline
\end{tabular}

*: Different from 1.0 at $\mathrm{P}<0.05$; **: Different from 1.0 at $\mathrm{P}<0.01$ 
GGE biplot analysis was employed for visual assessment of genotype $\mathrm{x}$ environment interaction with regard to green herbage yield. Biplot graphs created with different perspectives are presented in Figures 1, 2, 3 and 4. With these graphs, the genotypes exhibiting specific adaptation to each environment, the genotype with the best adaptation to all environments and ideal experimental environment were identified.
Eastern Anatolia has the most intensive pasturedependent livestock production. However, regional people experience several problems in feed supply during the winter months. To overcome this problem, silage maize culture is getting more common in the region. However, there are several registered maize cultivars in Turkey. Therefore, the cultivars with high green herbage yield in different environments of eastern Anatolia conditions should be identified.

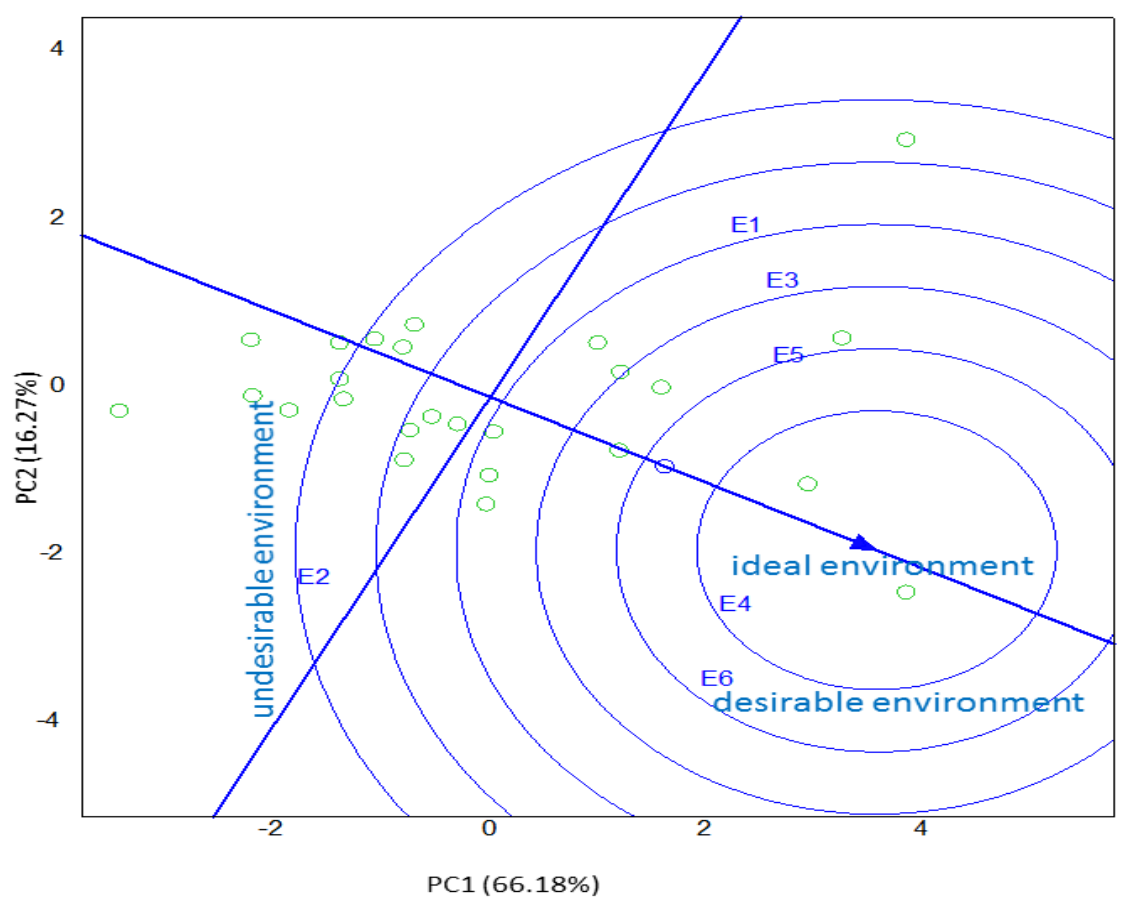

Figure 2. The discriminability and representativeness view of the GGE-biplot to show the discriminating ability and representativeness of the test environments for green herbage yield

GGE biplot method has usually used analysis of multienvironment experiments (Yan and Tinker, 2006). The method allows visual assessment of both the genotypes and environments (Yan et al., 2007). However, it hasn't been used widely in assessment of maize herbage yield in multi-environments. In present study, green herbage yields of 25 silage maize cultivars in 6 different environments (for 2 years at 3 locations) were analyzed. While the environments were able to explain $37.93 \%$ of total variation, cultivars and cultivar $\mathrm{x}$ environment interaction alone respectively explained 14.94 and $19.53 \%$ of total variation. Kaya et al. (2006) carried out a multienvironment research in wheat and reported the effect of environment as $81 \%$. Dehghani et al. (2006) also reported the similar ratios.

In GGE biplot analysis, genotype $\mathrm{x}$ environment interaction is separated into several principle components (PC) and graphically assessed (Kaya et al., 2006). If the first two principle components of GGE biplot are able to explain more than $60 \%$ of total variation $(\mathrm{G}+\mathrm{GE})$, then the method is assumed to explain total variation and the resultant graphs can reliably be used in assessments (Yan et al., 2001).

In present study, the first two principle components were able to explain about $82 \%$ of total variation. Then, 4 biplot graphs were created with different perspectives for assessments to be made.

The first graph was prepared to find out which genotype is well-perform in which environment (Figure 1). The graph was divided into 5 sectors, diagonal genotypes were identified in each sector and assessments were made based on positions of genotypes and environments over the graph. Six environments were placed in 3 different sectors and formed 3 mega environments. The environments E1, E3 and E5 formed the first mega environment, the environments E4 and E6 formed the second and the environment E2 alone formed the third mega environment. 


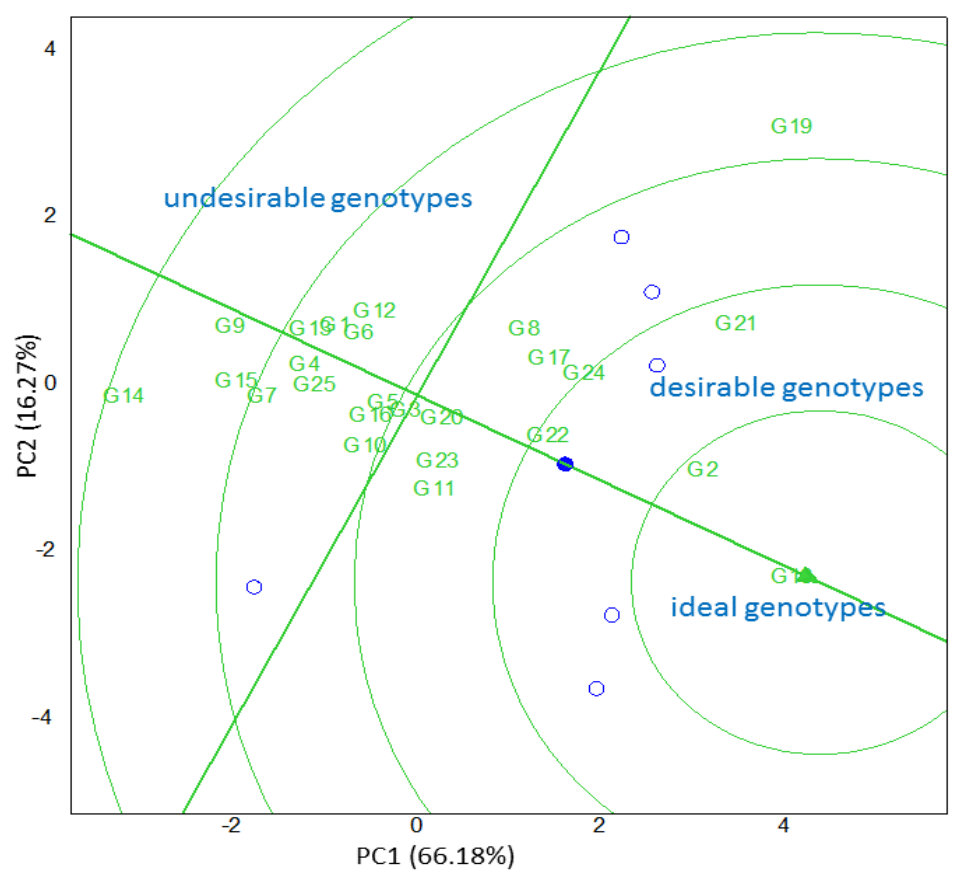

Figure 3. GGE-biplot based on genotype-focused scaling for comparison of the genotypes with ideal genotype for green herbage yield.

The genotypes Batem Efe (G19) and Burak (G21) were the diagonal cultivars in the first mega environment (E1, E3 and E5), the genotype Safak (G18) was the diagonal cultivar in the second mega environment (E4 and E6) and the genotypes Dian (G14) and DKC 6903 (G9) were the diagonals in the third mega environment (E2). These genotypes had the greatest green herbage yields in their environments.

Genotype stability was also assessed over the same graph. The genotypes with high PC1 and low PC2 values were assumed to be stable (Yan and Kang, 2003). The genotype Safak (G18) with these values was identified as the most stable cultivar. The regression coefficient of 1.0 and the greatest green herbage yield confirmed the stability of the cultivar. Generally the genotypes with high PC1 values [30B74 (G2), Seme Kukuruza 877 (G22), ADV 2898 (G24), Wayne (G17)] had higher green herbage yields than the general average. According to GGE biplot method, these cultivars can also be assessed as stable. However, regression coefficients of these cultivars were significantly different from 1.0. Therefore, these genotypes were not accepted as stable based on regression coefficients.

Discriminating power and representativeness view of the GGE- biplot is an important measure of testing environment (Dehghani et al., 2006). The length of concentric circles on the biplot helps to visualize the length of the environment vectors which is proportional to standard deviation within the respective environments on the biplot and also shows the discriminating ability of the environments (Yan, 2014). Thus, among 6 testing environments (Figure 2), E3, E4, E5 and E6 with long vector were the most discriminating, while E2 was the least discriminating environment. The test environments which are consistently non-discriminating provide little information on the genotype differences (Yan and Tinker, 2006) and/or the performances of all genotypes in testing environment were uniform.

The average environment axis (AEA) is presented in Figure 2. The average environment axis was intersected with a line passing through the origin of the biplot. Yan and Tinker (2006) indicated that the closer the environment to average environment axis (the smaller the angle is), the more efficient the environment is in assessment of genotypes. Then, environment E4 was identified as the ideal environment and environment E2 was identified as undesired environment. The ideal environment E4 allows the best assessment for the performance of genotypes (Yan et al., 2001; Jalata, 2011).

In genotype-focused graph of GGE biplot method, the maize cultivar/cultivars with a superior performance with regard to green herbage yield in majority/all of the environments were identified as ideal genotypes (Figure 3). In this graph, the circles created through the origin of the ideal genotype were used to assess the cultivars (Yan, 2014; Kaya et al., 2006). Then, the cultivars Safak (G18) and 30B74 (G2) were identified as the ideal genotypes; the cultivars of Burak (G21), Seme Kukuruza 877 (G22) and ADV 2898 (G24) were identified as desirable genotypes and the cultivar Dian (G14) was identified as undesirable genotype (Figure 3).

In environment-focused GGE biplot graph, average environment coordination (AEC) axis is able to separate genotypes based on their green herbage yields and stabilities (Figure 4). While all of the genotypes placed on 
the right side of AEC axis had higher green herbage yields than the average $\left(8.10\right.$ ton $\left.\mathrm{da}^{-1}\right)$, majority of the ones placed on the left side of AEC [except for Seme Kukuruza 873 (G23), DKC 7211 (G11)] had lower green herbage yields than the general average (Figure 4). Similar findings were reported in researches carried out with wheat and barley (Kaya et al., 2006; Jalata, 2011).

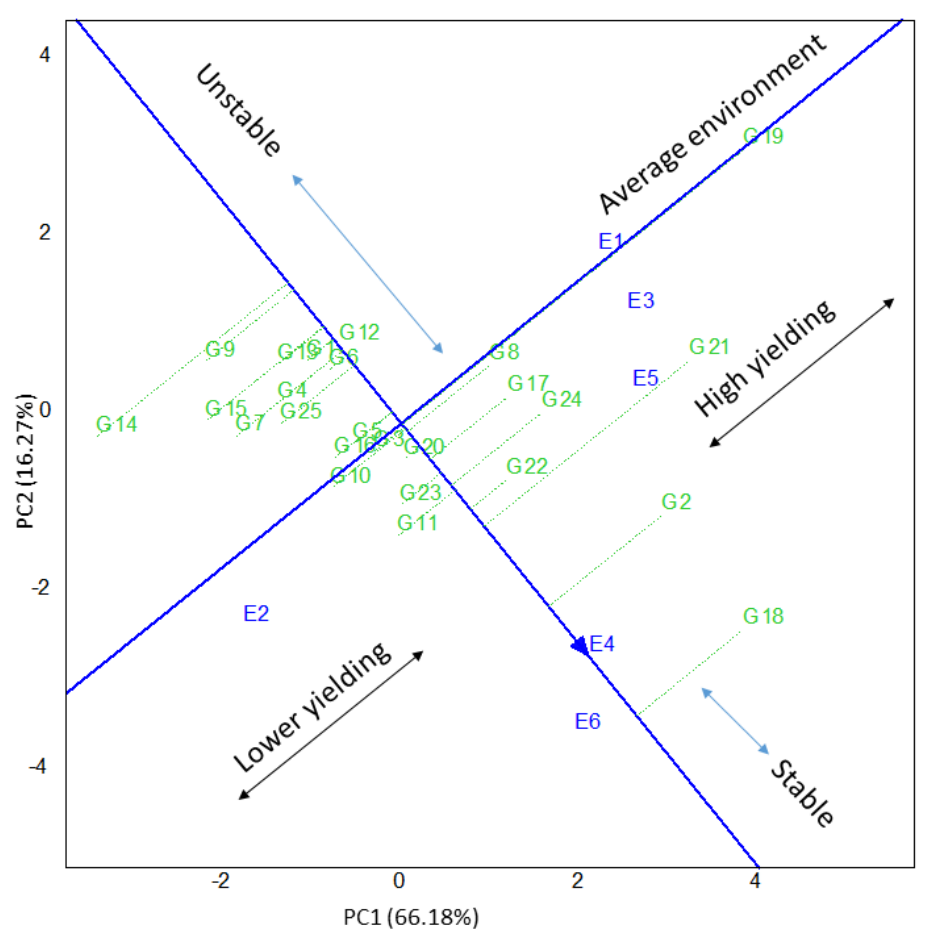

Figure 4. Average Environment Coordination (AEC) views of the GGE biplot based on environment focused scaling for the mean performance and stability of genotypes for green herbage yield.

For better adaptation by the growers, newly developed cultivars should be assessed for target attributes in different environments. The present study was conducted to assess green herbage yields of different maize cultivars in different environments and to identify the most stable cultivars. In GGE biplot analysis, genotype stability increased with increasing PC1 and decreasing PC2 values which were calculated from the green herbage yields of the cultivars. Among the investigated cultivars, Safak (G18) exhibited the best adaptation to all environments with regard to green herbage yield and the cultivar had the greatest green herbage yield and $b$ value of 1.0. Besides this cultivar, some others [30B74 (G2), Seme Kukuruza 877 (G22), ADV 2898 (G24), Wayne (G17)] with generally high PC1 values had higher green herbage yields than the general average and exhibited well adaptation to some environments. Based on GGE biplot method, these cultivars were also assessed as stable. However, they should be grown in environments in which they exhibited well-adaptation. It was concluded in present study that GGE biplot model could efficiently be used in assessment of green herbage yield yields of maize cultivars in different environments.

\section{LITERATURE CITED}

Akcura, M., Taner, S. and Kaya, Y. 2011. Evaluation of bread wheat genotypes under irrigated multi-environment conditions using GGE biplot analyses. Agriculture, 98(1), $35-40$.

Akcura, M., Y. Kaya, S. Taner and R. Ayranci. 2006. Parametric stability analyses for grain yield of durum wheat. Plant Soil Environ. 52:254-261.

Akcura, M., Y. Kaya and S. Taner. 2005. Genotype-environment 1nteraction and phenotypic stability analysis for grain yield of durum wheat in Central Anatolian Region. Turkish J. Agric. For. 29:369-375.

Annicchiarico, P. 1997. Joint regression vs. AMMI analysis of genotype-environment interactions for cereals in Italy. Euphytica 94:53-62.

Dehghani, H., A. Ebadi and A. Yousefi. 2006. Biplot analysis of genotype $x$ environment interaction for barley yield in Iran. Agron. J. 98: 388-393.

Eberhart, S.A. and W.A. Russell. 1966. Stability parameters for comparing varieties. Crop Sci. 6:36-40.

Flores, F., M.T. Moreno and J.I. Cubero. 1998. A comparison of univariate and multivariate methods to analyze environments. Field Crop Res. 56:271-286.

Francis, T.R. and L.W. Kannenberg. 1978. Yield stability studies in short season maize 1. A descriptive method for grouping genotypes. Can. J. Plant Sci. 58:1029-1034.

Gauch, G.H. and Zobel, R.W. 1988. Predictive and postdictive success of statistical analyses of yield trials. Theor. Appl. Genet. 76: 1-10.

Jalata, Z. 2011. GGE-biplot analysis of multi-environment yield trials of barley (Hordeum vulgare L.) genotypes in Southeastern Ethiopia highlands Int. J. Plant Breed. Genet. 5(1):59-75. 
Kandus, M., D. Almorza, R. Boggio Ronceros and J.C. Salerno. 2010. Statistical models for evaluating the genotypeenvironment interaction in maize (Zea mays L.). Phyton (Buenos Ares) 79:39-45.

Kaplan, M. 2005. Effects of different intra and inter row spacing on yield and yield components of second crop silage maize (Zea mays L.) under Kahramanmaras conditions. MSc Thesis, University of Kahramanmaras Sutcu Imam Kahramanmaras Turkey.

Kaplan, M., O. Baran, A. Unlukara, H. Kale, M. Arslan, K. Kara, S. Buyukkilic Beyzi, Y. Konca and A. Ulas. 2016. The effects of different nitrogen doses and irrigation levels on yield, nutritive value, fermentation and gas production of corn silage. Turk J. Field Crops 2(1):100-108.

Kaya, Y., M. Akcura and S. Taner. 2006. GGE-Biplot analysis of multi-environment yield trials in bread wheat. Turk J. Agric. 30:325-337.

McDonald, P. A.R. Henderson and S.J.E. Heron. 1991. The Biochemistry of Silage. Second Edition. 340 p. Chalcombe Publication.

Meeske. R., G. Ashbell, Z.G. Weinberg and T. Kipnis. 1993. Ensiling forage sorghum at two stages of maturity with the addition of lactic acid bacterial inoculants. Anim. Feed Sci. Technol. 43:165-175.

Nachit, M.M., M.E. Sorrells, R.W. Zobel, H.G. Gauch, R.A. Fischer and W.R. Coffman. 1992. Association of environmental variables with sites' mean grain yield and components of genotype-environment interaction in durum wheat. J. Gene. Breed Org. 46:369-372.

Neylon, J.M. and L. Kung. 2003. Effects of cutting height and maturity on the nutritive value of corn silage for lactating cows. J. Dairy Sci. 86:2163-2169.

R Development Core Team. 2008. R: a language and environment for statistical computing. R Foundation for Statistical Computing, Vienna, Austria. ISBN 3-900051-070. http://www.R-project.

Rakshit, S., K.N. Ganapathy, S.S. Gomashe, A. Rathore, R.B. Ghorade, M. Kumar, K. Kumar, S.K. Ganesmurthy, M.Y. Jain, J.S. Kamtar, S.S. Sachan, B.R. Ambekar, D.G. Ranwa,
M. Kanawade, D. Balusamy, A. Kadam, V.A. Sarkar and J.V. Tonapi. 2012. GGE biplot analysis to evaluate genotype, environment and their interactions in sorghum multi-location data. Euphytica 185(3):465-479.

SAS. 2014. SAS: Business analytics and business intelligence software. SAS Inst. http://www.sas.com/en_us/home.html.

Shukla, G.K. 1972. Some statistical aspects of partitioning genotype environmental components of variability. Heredity 29:237-245.

Yan, W. 1999. Methodology of cultivar evaluation based on yield trial data-with special reference to winter wheat in Ontario. Ph.D Thesis, University of Guelph, Guelph, ON, Canada.

Yan, W. and L.A. Hunt. 1998. Genotype by environment interaction and crop yield. Plant Breed Rev. 16:35-178

Yan, W., L.A. Hunt, Q. Sheng and Z. Szlavnics. 2000. Cultivar evaluation and mega-environment investigation based on GGE biplot. Crop Sci. 40:597-605.

Yan, W., P.L. Cornelius, J. Crossa and L.A. Hunt. 2001. Two types of GGE Biplots for analyzing multi-environment trial data. Crop Sci. 41:656-663.

Yan, W. and M.S. Kang. 2003. GGE Biplot Analysis: A Graphical Tool for Breeders, Geneticists and Agronomists. 1st Edn, CRC Press LLC, Boca Roton, Florida, pp: 271.

Yan, W. and N.A. Tinker. 2006. Biplot analysis of multienvironment trial data: Principles and applications. Can. J. Plant Sci. 86:623-645.

Yan, W. 2014. Crop variety trials: Data management and analysis. John Wiley and Sons. pp. 349.

Yan, W., Tinker, N.A., Molnar, S., Fregeau-Reid, J. and McElroy, A. 2007. Associations among oat traits and their responses to the environment in North America. Journal of Crop Improvement 20:1-29.

Yan, W. 1999. A study on the methodology of cultivar evaluation based on yield trial data - with special reference to winter wheat in Ontario, Ph.D. thesis, University of Guelph, Guleph, Ontario, Canada.

Zobel, R.W., M.J. Wright and H.G. Gauch, Jr. 1988. Statistical analysis of a yield trial. Agron. J. 80:388-393. 